\title{
Application of Polyacrylamide Gel Electrophoresis to the Characterization and Identification of Arthrobacter Species $\dagger$
}

\author{
JULIE A. SEITER AND JAMES M. JAY \\ Department of Biological Sciences, Wayne State University, Detroit, Michigan 48202
}

\begin{abstract}
When polyacrylamide gel electrophoretic profiles of soluble proteins of seven Arthrobacter strains were compared with those of seven coryneform and coryneform-like species, the arthrobacters were delineated from the latter species. Comparisons were made from a composite gel by calculating similarity coefficients. When Arthrobacter globiformis was used as a reference, similarity coefficients for the other Arthrobacter species ranged from 20.7 to 34.5, but the similarity coefficients for the other genera tested were only 7.9 to 18.5. In addition to a separation of arthrobacters from other coryneforms by this method, Arthro. bacter crystallopoites and Arthrobacter pyridinolis had a similarity coefficient of approximately 95, which set these two apart from the other Arthrobacter species studied and furthermore suggested that they represent one species. Gel electrophoresis of soluble proteins may provide a good alternative to the use of rod to coccoid transition for identifying arthrobacters since it is faster and simpler to perform than chemical analyses of cell wall components.
\end{abstract}

Arthrobacters are aerobic, nonsporeforming, gram-positive bacteria which change morphology during growth from pleomorphic rods when young to coccoids as they age. Because the genus description is based on this morphological cycle (3), there is confusion about the taxonomy of Arthrobacter and related genera, some of which exhibit less pronounced life cycles. The genus Arthrobacter is included in the coryneform group, which includes three other genera according to Bergey's Manual of Determinative Bacteriology, 8th ed. (2), namely Cellulomonas, Corynebacterium, and Kurthia. Some authors include the genera Brevibacterium and Microbacterium (10), whereas cell wall composition studies link Nocardia and Mycobacterium with the coryneforms (4). A morphological cycle of development has been observed in representatives of all coryneform genera. The observations range from strains which undergo complete cycles to those in which some cells show a shortening with age. The variability even occurs within species, depending on culture conditions and media. Thus, identification of arthrobacters solely on the basis of morphological life cycles has limitations.

Although serological methods have been useful for taxonomy and rapid identification in a number of bacterial families, very little work has been done on arthrobacters (4-6), probably due to the poor antigenicity of members of this genus. Yamada and Komagata (13) designed a key

† Contribution no. 389 from the Department of Biological
Sciences, College of Liberal Arts, Wayne State University. for seven genera of coryneforms based on principal cell wall amino acids, mode of division, deoxyribonucleic acid composition, and biochemical and physiological characteristics. Their scheme for dividing coryneform genera indicated that many strains may have been improperly identified. The methods employed by these investigators are time consuming at best.

More recently, Stackebrandt and Fiedler (9) studied deoxyribonucleic acid-deoxyribonucleic acid homologies among 16 strains of Arthrobacter and found a homology range between 11 and $55 \%$ to the type strain of the type species, $A$. globiformis ATCC 8010. For two strains of $A$. globiformis tested, a homology of only $30 \%$ was found. These findings emphasize the need for a better understanding of the taxonomic relationships of the coryneforms in general and the arthrobacters in particular.

Therefore, it was the aim of this study to investigate the use of polyacrylamide gel electrophoresis for differentiating arthrobacters from other coryneforms on the basis of their soluble protein fractions and to assess the efficacy of employing this method in the routine identification of arthrobacters.

\section{MATERIALS AND METHODS}

Bacterial strains and growth conditions. The bacterial strains studied and their sources are shown in Table 1. All strains were maintained on Trypticase soy agar (BBL Microbiology Systems) incubated at $30^{\circ} \mathrm{C}$ and stored at $2^{\circ} \mathrm{C}$. Large volumes of cells were grown in 125-ml amounts of Trypticase soy broth in 250 -ml Erlenmeyer flasks. The flasks were seeded with 1 to $2 \mathrm{ml}$ of 24-h-old Trypticase soy broth cultures and 
TABLE 1. Strains employed in this study

\begin{tabular}{|c|c|c|}
\hline $\begin{array}{l}\text { Study no. } \\
\text { of strain }\end{array}$ & Species & $\begin{array}{c}\text { Strain } \\
\text { designation }\end{array}$ \\
\hline 1 & A. globiformis & ATCC $8010^{a}$ \\
\hline 2 & A. globiformis & ATCC $4336^{a}$ \\
\hline 3 & A. crystallopoites & WSU $502^{b}$ \\
\hline 4 & A. pyridinolis & WSU $503^{b}$ \\
\hline 5 & A. atrocyaneus & WSU $504^{b}$ \\
\hline 6 & A. tumescens & ATCC $6947^{a}$ \\
\hline 7 & A. simplex & ATCC $6946^{a}$ \\
\hline 8 & Corynebacterium sp. & WSU $280^{\circ}$ \\
\hline 9 & $\begin{array}{l}\text { Corynebacterium stria- } \\
\text { tum }\end{array}$ & ATCC $6940^{a}$ \\
\hline 10 & Brevibacterium taipei & ATCC $13744^{a}$ \\
\hline 11 & $\begin{array}{l}\text { Cellulomonas flavi- } \\
\text { gena }\end{array}$ & $\operatorname{ATCC} 482^{a}$ \\
\hline 12 & $\begin{array}{l}\text { Mycobacterium smeg. } \\
\text { matis }\end{array}$ & WSU $180^{d}$ \\
\hline 13 & Mocardia coeliaca & $\operatorname{ATCC} 13181^{a}$ \\
\hline 14 & Kurthia zopfii & ATCC $10538^{a}$ \\
\hline
\end{tabular}

${ }^{a}$ Obtained from the American Type Culture Collection, Rockville, Md.

${ }^{b}$ Originally obtained from T. A. Krulwich, City University of New York.

${ }^{c}$ Isolated from kerosene.

${ }^{d}$ Common laboratory strain.

incubated at $30^{\circ} \mathrm{C}$ on a rotary shaker at $120 \mathrm{rpm}$ for $48 \mathrm{~h}$.

Preparation of soluble extract. The cells from a 48-h-old culture were harvested by centrifugation at $12,000 \times g$ under refrigeration in an IEC model B-50 ultracentrifuge and were washed three times in physiological saline, $\mathrm{pH}$ 7.4. The final pellet of cells was suspended in either $0.6 \mathrm{~N} \mathrm{KCl} \mathrm{(pH} \mathrm{7.4)} \mathrm{or} \mathrm{pH} 7.4$ phosphate buffer (ionicity, 0.12 ; ratio of buffer to cells to $5-\mu \mathrm{m}$ glass beads, $3: 1: 1)$. Volumes $(10 \mathrm{ml})$ of cell suspensions were disintegrated in a model W 350 sonicator (Heat Systems-Ultrasonics, Inc.) at maximum output for 20 to $25 \mathrm{~min}$ while submerged in an ice bath. The suspensions were centrifuged twice at 4,000 $\times g$ to remove the beads and heavy particulate matter. The supernatant contained the soluble fraction from the cells. Protein estimations were done by the biuret method described by Brewer et al. (1). All fractions were stored in screw-capped vials at $-20^{\circ} \mathrm{C}$.

Polyacrylamide gel electrophoresis. Vertical anionic slab gel electrophoresis (gel size, 24 by $17 \mathrm{~cm}$ ) was carried out on the soluble bacterial fractions with a model 490 electrophoresis unit (E-C Apparatus Co.). The discontinuous system consisted of a $4 \%$ stacking gel followed by a $10 \%$ running gel made with acrylamide grout; the samples were allowed to move about $10 \mathrm{~cm}$ at 250 to $300 \mathrm{~V}$ and approximately $100 \mathrm{~mA}$. The stacking gel contained $0.1 \mathrm{M}$ tris(hydroxymethyl)aminomethane $[7.5 \mathrm{~g}$ of tris(hydroxymethyl)aminomethane per liter, adjusted to $\mathrm{pH} 6.7$ with $\mathrm{HCl}]$, and the running gel contained $0.5 \mathrm{M}$ of tris(hydroxymethyl)aminomethane per liter, [46 $\mathrm{g}$ of tris(hydroxymethyl)aminomethane per liter adjusted to $\mathrm{pH} 8.9$ with $\mathrm{HCl}$ ]. The $\mathrm{pH} 8.30 .04 \mathrm{M}$ compartment buffer was made with tris(hydroxy-methyl)aminomethane $(0.6 \mathrm{~g} / \mathrm{liter})$ and glycine $(2.9 \mathrm{~g} / \mathrm{liter})$. The sample size of the soluble fraction was adjusted to apply $200 \mu \mathrm{g}$ of protein, which was mixed with bromophenol blue crystals as a tracking dye and with sucrose crystals.

Staining was in $0.2 \%$ Coomassie brilliant blue in $50 \%$ methanol- $7 \%$ glacial acetic acid for $1 \mathrm{~h}$ at $37^{\circ} \mathrm{C}$ (7). After the gels were destained electrophoretically in methanol-water-glacial acetic acid (5:5:1), they were stored in $7 \%$ glacial acetic acid. $R_{f}$ values were calculated by the following relationship: $R_{f}=d / d_{s}$ where $d$ is the distance from the origin to the sample protein band and $d_{s}$ is the distance from the origin to the solvent front marked by bromophenol blue.

Because of the variability of several factors in gel electrophoresis, such as voltage fluctuations and differences in batches of acrylamide grout, the absolute migration distances of proteins were not exactly reproducible. To aid in the comparison of gels, the type strain of the type species (A. globiformis ATCC 8010) and other arthrobacters were run on each gel.

To determine whether the protein profiles were stable and could be compared, ATCC 8010 was grown under a variety of conditions (Table 2). Soluble fractions were prepared from the cells, and the fractions were run on gel electrophoresis.

\section{RESULTS}

All major protein bands present in soluble extracts of $A$. globiformis ATCC 8010 grown under the standard conditions of this study were also present when the strain was grown under a variety of conditions. However, there were variations in some of the weaker bands. When the standard conditions were used, duplicate preparations produced nearly identical protein profiles when they were run on the same gel. Throughout the study, carefully controlled growth conditions were maintained.

Comparison of several gels from polyacrylamide gel electrophoresis showed that although the pattern of protein bands remained the same for each strain, there was enough variation in the way the gels ran that $\boldsymbol{R}_{f}$ values could not be directly compared from gel to gel. To circumvent this problem, a composite of several gels was drawn by using the $A$. globiformis ATCC 8010 profile (Fig. 1) as a reference.

TABLE 2. Growth conditions used to determine stability of A. globiformis ATCC 8010 protein profiles on polyacrylamide gel electrophoresis

\begin{tabular}{llccc}
\hline \multicolumn{1}{c}{ Conditions } & Medium $^{\alpha}$ & pH & Temp $\left({ }^{\circ} \mathrm{C}\right)$ & Time (h) \\
\hline $\begin{array}{l}\text { Standard } \\
\text { Variations }\end{array}$ & TSB & 7.4 & 30 & 48 \\
1 & & & & \\
2 & AOAC & & & \\
3 & & 8.4 & & \\
4 & & & 15 & \\
5 & & & & 72 \\
\hline
\end{tabular}

${ }^{a}$ TSB, Trypticase soy broth. AOAC, Synthetic broth AOAC (Difco). 
The composite (Fig. 2) was based on a selected gel which contained all but 3 of the 14 strains studied (the Mycobacterium, Nocardia, and Kurthia strains) and on three to five additional gels. The protein profiles of these three strains were transposed to the proportions of the master gel by using the $R_{f}$ values of the major protein bands of $A$. globiformis ATCC 8010 and of the

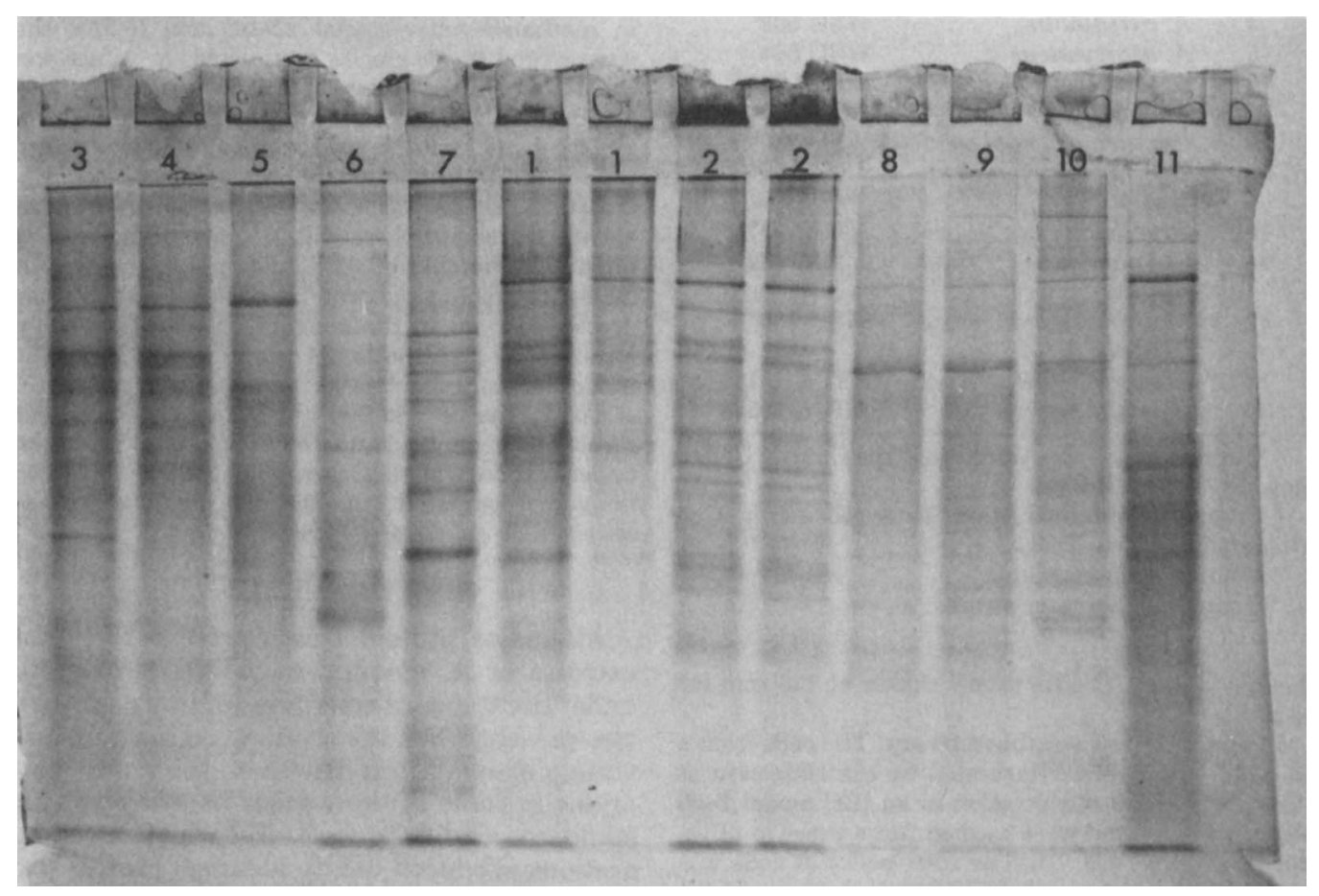

Fic. 1. Sodium dodecyl sulfate-polyacrylamide gel electrophoresis of 11 coryneforms (see Table 1 for strain identifications).

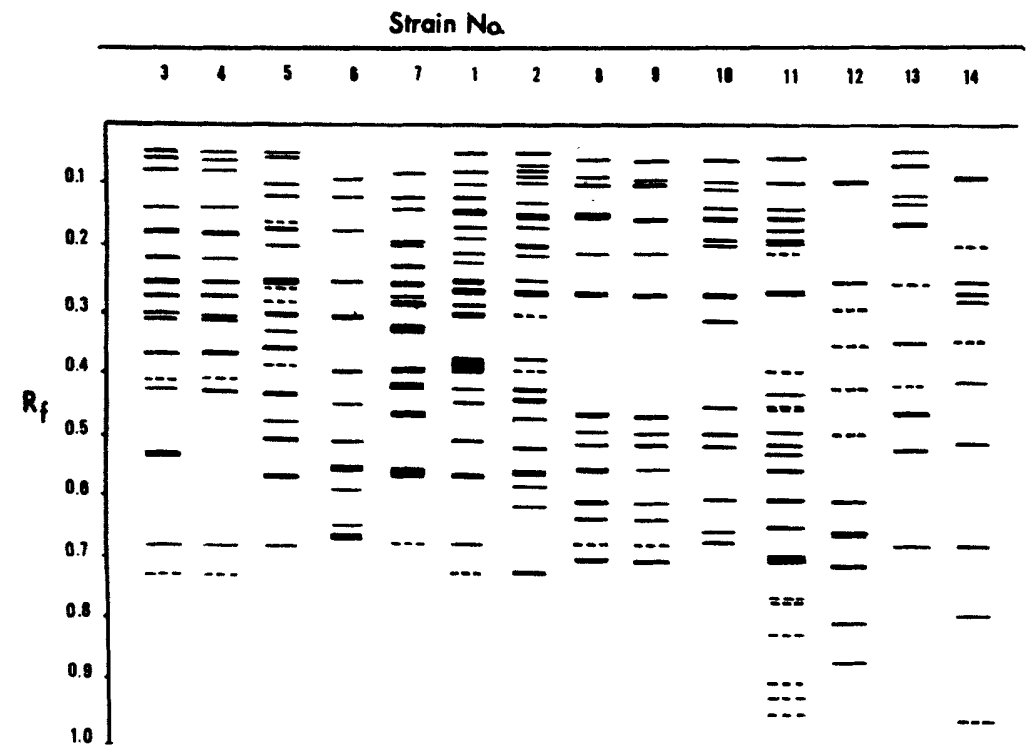

Fig. 2. Protein profiles of 14 coryneforms drawn as a composite from three to five electrophoretic gels (see Table 1 for strain identifications). 
other Arthrobacter strains as reference points. The $R_{f}$ values of easily identified bands on the master gel $\left(R_{f}\right)$ were compared with the $R_{f}$ values of the corresponding bands on the additional gels $\left(\boldsymbol{R}_{f}^{\prime}\right)$, and a conversion factor $(f)$ was calculated as follows $f=R_{f} / R_{f}^{\prime}$. The $R_{f}$ value of each band on each additional gel was multiplied by $f$ in order to determine its relative position on the master gel.

The composite gel shows from 9 to 23 bands per species. The bands occupy 63 different positions, as determined by $\boldsymbol{R}_{f}$ values. Coefficients of similarity $(S)$ were calculated by the similarity coefficient of Jaccard (8) for each pair of the 14 strains studied. The formula for this coefficient is as follows: $S=m /(m+u)$, where $m$ is the number of matched pairs of bands and $u$ is the number of unmatched pairs. Negative matches (cases where neither population possessed a band) were not considered. These coefficients of similarity $(\times 100)$ are summarized in Table 3 .

No band was present in the strains of all seven Arthrobacter species. The two strains of A. globiformis shared 16 bands, giving them a similarity coefficient of 57.1. Visually, the protein profiles of these two strains appeared very similar. The similarity coefficients between each of the $A$. globiformis strains and the other Arthrobacter strains were between 21 and 35 , whereas the coefficients with the other coryneforms ranged from 8 to 19 . Seven bands were shared by the Arthrobacter crystallopoites, Arthrobacter pyridinolis, and Arthrobacter atrocyaneus strains and the two A. globiformis strains. The number of shared bands dropped to two when Arthrobacter simplex ATCC 6946 was included in this group. The protein profiles of $A$. crystallopoites WSU 502 and $A$. pyridinolis WSU 503 looked very similar and differed by only one band; their coefficient of similarity was 93.8 . The coefficients of these two strains with Arthrobacter tumes. cens ATCC 6947 were 3.7 and 3.8, respectively. In general, the protein profiles of the $A$. globiformis strains were more closely related to profiles of confirmed Arthrobacter strains than to the profiles of non-arthrobacters.

\section{DISCUSSION}

The work reported here is a preliminary effort to determine what contribution gel electrophoresis of soluble proteins might make toward the clarification of the taxonomy of arthrobacters. Seven strains of Arthrobacter were compared with seven other coryneforms. A comparison of the characters regularly used in the taxonomy of these organisms is shown in Table 4. The outstanding feature of arthrobacters (rod to coccoid transition) was found to be inconsistent; strains of two species $(A$. pyridinolis and $A$. crystallopoites) produced coccoids in $24 \mathrm{~h}$, whereas others required several days. This finding points out the need for a taxonomic criterion other than rod to coccoid transition for the identification of arthrobacters. Although serological methods have been useful in the taxonomy of a number of bacterial families, the low antigenicity of some coryneform bacteria hinders this approach with these organisms. A. globiformis ATCC 8010 antiserum prepared in rabbits shared agglutinins with four of six Arthrobacter strains studied and with one of seven of the other coryneforms (Table 4). This absence of serological specificity for arthrobacters agrees with the results from other studies $(4,6)$.

The choice of electrophoretic assay for general proteins in this study was prompted by the search for a simple and quick way of identifying strains suspected of being arthrobacters. The

TABLE 3. Similarity coefficients $(\times 100)$ calculated from composite protein profiles of 14 coryneforms

\begin{tabular}{|c|c|c|c|c|c|c|c|c|c|c|c|c|c|c|}
\hline \multirow{2}{*}{$\begin{array}{c}\text { Strain } \\
\text { no. }^{a}\end{array}$} & \multicolumn{14}{|c|}{ Similarity coefficients with the following strains: } \\
\hline & 1 & 2 & 3 & 4 & 5 & 6 & 7 & 8 & 9 & 10 & 11 & 12 & 13 & 14 \\
\hline 1 & 100 & & & & & & & & & & & & & \\
\hline 2 & 57.1 & 100 & & & & & & & & & & & & \\
\hline 3 & 32.1 & 26.7 & 100 & & & & & & & & & & & \\
\hline 4 & 30.8 & 27.6 & 93.8 & 100 & & & & & & & & & & \\
\hline 5 & 34.5 & 28.1 & 17.1 & 17.9 & 100 & & & & & & & & & \\
\hline 6 & 22.2 & 20.7 & 3.7 & 3.8 & 15.4 & 100 & & & & & & & & \\
\hline 7 & 32.1 & 21.9 & 18.5 & 19.2 & 25.9 & 7.7 & 100 & & & & & & & \\
\hline 8 & 12.9 & 15.6 & 11.1 & 11.5 & 14.3 & 4.0 & 15.4 & 100 & & & & & & \\
\hline 9 & 12.9 & 15.6 & 11.1 & 11.5 & 14.3 & 4.0 & 15.4 & 100 & 100 & & & & & \\
\hline 10 & 9.4 & 9.1 & 14.3 & 16.0 & 14.3 & 0 & 15.4 & 33.3 & 33.3 & 100 & & & & \\
\hline 11 & 11.4 & 7.9 & 17.2 & 13.8 & 16.1 & 3.4 & 17.2 & 45.5 & 45.5 & 52.4 & 100 & & & \\
\hline 12 & 10.7 & 10.0 & 8.3 & 12.5 & 16.7 & 4.8 & 4.0 & 9.1 & 9.1 & 9.1 & 7.7 & 100 & & \\
\hline 13 & 18.5 & 17.2 & 12.5 & 13.0 & 16.0 & 9.5 & 22.7 & 8.7 & 8.7 & 0 & 0 & 5.0 & 100 & \\
\hline 14 & 11.1 & 18.5 & 8.7 & 9.1 & 12.5 & 5.0 & 16.0 & 21.1 & 21.1 & 21.1 & 21.1 & 5.3 & 17.6 & 100 \\
\hline
\end{tabular}

\footnotetext{
${ }^{a}$ See Table 1.
} 
TABLE 4. Comparison of arthrobacters with other coryneforms relative to various taxonomic characters

\begin{tabular}{|c|c|c|c|}
\hline Character & Arthrobacters & Other coryneforms & Comments \\
\hline Gram reaction & Positive & Positive & \\
\hline $\begin{array}{l}\text { Cell arrangement and } \\
\text { shape }\end{array}$ & Coryneform & Coryneform & \\
\hline $\begin{array}{l}\text { Rod to coccoid } \\
\text { transition }\end{array}$ & Generally positive & Generally negative & $\begin{array}{l}\text { Some arthrobacters produced } \\
\text { coccoids in } 24 \mathrm{~h} \text {, and some } \\
\text { required } 9 \text { days under the } \\
\text { standard conditions of this } \\
\text { study }\end{array}$ \\
\hline $\begin{array}{l}\text { Guanine plus cytosine } \\
\text { content of } \\
\text { deoxyribonucleic } \\
\text { acid (mol\%) }\end{array}$ & $60-72$ & $52-71$ & See reference 12 \\
\hline $\begin{array}{l}\text { Principal amino acids } \\
\text { in cell wall }\end{array}$ & $\begin{array}{l}\text { Mostly lysine; some } \\
\text { LL-diaminopimelic } \\
\text { acid }\end{array}$ & $\begin{array}{l}\text { DL- or LL- } \\
\text { diaminopimelic acid } \\
\text { or lysine }\end{array}$ & See reference 11 \\
\hline $\begin{array}{l}\text { Heterologous } \\
\text { agglutinins to } A \text {. } \\
\text { globiformis ATCC } \\
8010\end{array}$ & $\begin{array}{l}\text { Four of six strains } \\
\text { positive }\end{array}$ & $\begin{array}{l}\text { One of seven strains } \\
\text { positive }\end{array}$ & $\begin{array}{l}\text { Agglutinins at titer of } 1: 8 \text { and } \\
\text { above. } A \text {. pyridinolis WSU } \\
503 \text { and } A \text {. crystallopoites } \\
\text { WSU } 502 \text { were negative } \\
\text { (unpublished data) }\end{array}$ \\
\hline $\begin{array}{l}\text { Similarity coefficients } \\
\text { of soluble proteins }\end{array}$ & $20.7-34.5$ & $7.9-18.5$ & $\begin{array}{l}\text { Referenced to } A \text {. globiformis } \\
\text { ATCC 8010; data from } \\
\text { Table } 2\end{array}$ \\
\hline
\end{tabular}

disadvantage of not knowing the identity of a specific protein should be outweighed by the advantage of being able to examine a large number of alleles at one time.

Gel electrophoresis of the soluble proteins of the 14 organisms tested clearly separated the arthrobacters from the other coryneforms examined. This was evident when similarity coefficients were used for the comparison. When $A$. globiformis ATCC 8010 was used as a reference for stained bands, the similarity coefficients for the other Arthrobacter strains ranged from 20.7 to 34.5 . On the other hand, the coefficients between $A$. globiformis and the other coryneforms ranged from 7.9 to 18.5 .

Among the Arthrobacter strains, A. tumescens ATCC 6947 was remarkable for the low similarity coefficients which it had with $A$. crystallopoites WSU 502, A. pyridinolis WSU 503, A. simplex ATCC 6946, and even $A$. globiformis ATCC 8010 . Based on agglutinin studies (6), $A$. tumescens ATCC 6947 was thought to hold an ancestral position, but examination by gel electrophoresis did not confirm this.

The strains of $A$. crystallopoites and $A$. pyri. dinolis had a similarity coefficient of approximately 94. Since this value is considerably higher than the values exhibited by other $A r$. throbacter strains and since these two strains gave similar results when rod to coccoid transition times and agglutinin titers were examined in this laboratory, it is likely that these two strains should be placed in the same species.

Although the combined use of deoxyribonucleic acid composition, principal amino acids in cell walls, and mode of division, as proposed by Yamada and Komagata (13), did appear to delineate clusters of coryneforms which corresponded to genera, this approach creates some clusters of strains which do not fit into any of the recognized genera. The work of these investigators assumes that many strains have been misnamed on the basis of superficial criteria.

This study has followed the more conservative approach of examining the potential of a method (in this case gel electrophoresis of soluble protein fractions) to delineate known Arthrobacter strains from other coryneforms. Since a limited number of strains was included in this study, further work needs to be done with other named and unnamed isolates of Arthrobacter and other coryneform strains to test this taxonomic method. The findings of this study show that the differentiation of arthrobacters from other coryneforms could possibly be made by analysis of soluble protein fractions by gel electrophoresis. Gel electrophoresis is a relatively rapid procedure which could easily lend itself to routine examination of strains suspected of being arthrobacters.

\section{REPRINT REQUESTS}

Address reprint requests to: Dr. James M. Jay, Department of Biology, Wayne State University, Detroit, MI 48202. 


\section{LITERATURE CITED}

1. Brewer, J. M., A. J. Pesce, and R. B. Ashworth. 1974 Experimental techniques in biochemistry. PrenticeHall, Inc., Englewood Cliffs, N. J.

2. Buchanan, R. E., and N. E. Gibbons (ed.). 1974. Bergey's manual of determinative bacteriology. The Williams \& Wilkins Co., Baltimore.

3. Conn, H. J., and I. Dimmick. 1947. Soil bacteria similar in morphology to Mycobacterium and Corynebacte. rium. J. Bacteriol. 54:291-303.

4. Cummins, C. S. 1962 . Chemical composition and antigenic structure of cell walls of Corynebacterium, Mycobacterium, Nocardia, Actinomyces and Arthrobac ter. J. Gen. Microbiol. 28:35-50.

5. Holland, A. A., T. R. G. Gray, and B. M. Luscombe. 1972. Immunodiffusion and fluorescent antibody methods to distinguish rod and coccoid forms of a species of Arthrobacter. Antonie van Leeuwenhoek J. Microbiol. Serol. 38:169-176.

6. Katzoelson, H., and A. Mason. 1962. Serological relationships among species of Arthrobacter. Can J. Microbiol. 8:588-591.
7. Maizel, J. V. 1971. Polyacrylamide gel electrophoresis of viral proteins, p. 179-246. In $\mathrm{K}$. Maramorosh and $\mathrm{H}$. Koprowski (ed.), Methods in virology, vol. 5. Academic Press Inc., New York.

8. Sneath, P. H. A. 1957. The application of computers to taxonomy. J. Gen. Microbiol. 17:201-226.

9. Stackebrandt, E., and F. Fiedler. 1979. DNA-DNA homology studies among strains of Arthrobacter and Brevibacterium. Arch. Microbiol. 120:289-295.

10. Veldkamp, H. 1970. Saprophytic coryneform bacteria. Annu. Rev. Microbiol. 24:209-240.

11. Yamada, K., and K. Komagata. 1970. Taxonomic studies on coryneform bacteria. II. Principal amino acids in the cell wall and their taxonomic significance. J. Gen. Appl. Microbiol. 16:103-113.

12. Yamada, K., and K. Komagata. 1970. Taxonomic studies on coryneform bacteria. III. DNA base composition of coryneform bacteria. J. Gen. Appl. Microbiol. 16: 215-224.

13. Yamada, K., and K. Komagata. 1972. Taxonomic studies on coryneform bacteria. V. Classification of coryneform bacteria. J. Gen. Appl. Microbiol. 18:417-431. 